\title{
IMPROVING STUDENT ACHIEVEMENT IN THE SUBJECTS OF ISLAMIC RELIGIOUS EDUCATION
}

\author{
Ahmad Yasa \\ Faculty of Islamic Studies, Islamic University of Nusantara, Bandung-Indonesia \\ Jl. Soekarno Hatta No. 530 Bandung-Indonesia \\ E-mail: ahmadyasa@gmail.com
}

\section{Imam Asrofi}

E-mail: asyrofy_jw@yahoo.com

\begin{abstract}
The purpose of this study was (1) to know a difference between student learning outcomes of low and high sub groups with learning to use the media worksheets in the subjects of Islamic Religious Education (Pendidikan Agama Islam); and (2) to know the obstacles in the implementation of learning by using the worksheets on the subject. The subjects study were three Open Junior High Schools, Bandung, namely Open Junior High School 8 Bandung, Open Junior High School 27 Bandung, and Open Junior High School 36 Bandung. The hypothesis tested the increase in student achievement in the subjects of Islamic Religious Education after a learning process using worksheets. This study was a quasi-experimental study. The design used in this study is a pre-test post-test one group design. The results show that learning outcomes after the use of worksheets has no significant difference. Then the t-test Test Final Problem Description pretest and posttest seen that the value of significance (sig.2-tailed) with the t-test is 0.007 . Since the significance value less than 0.05 then the decision-making criteria, $\mathrm{H}_{0}$ rejected. This shows that learning outcomes after the use of worksheets has significant difference. Using the analysis, the results showed that the use of worksheets in the learning process could improve the learning outcomes of students in the subjects of Islamic Religious Education in junior high school in Bandung.
\end{abstract}

Keywords: Islamic Religious Education, Worksheet, Achievement.

\begin{abstract}
ABSTRAK
[Tujuan dilakukannya penelitian ini adalah 1). Apakah terdapat perbedaan antara hasil belajar siswa antara sub kelompok rendah, dan sub kelompok tinggi dengan pembelajaran menggunakan media LKS pada mata pelajaran Pendidikan Agama Islam 2). Apa hambatan dalam implementasi pembelajaran dengan menggunakan LKS pada mata pelajaran Pendidikan Agama Islam. Subjek penelitian ini adalah tiga SMP Terbuka Kota Bandung, yaitu SMP Terbuka Induk SMP Negeri 8 Bandung, SMP Terbuka Induk SMP Negeri 27 Bandung dan SMP Terbuka Induk SMP Negeri 36 Bandung. Hipotesis yang diuji adalah adanya peningkatan prestasi belajar siswa pada mata pelajaran PAI setelah melakukan proses pembelajaran dengan menggunakan LKS. Penelitian ini merupakan penelitian kuasi eksperimen. Desain yang digunakan dalam penelitian ini adalah pre-test post-test one group design. Maka berdasarkan hasil penelitian yang diperoleh babwa Uji-t Tes Soal Pilihan Ganda Pretes dan Postes terlihat
\end{abstract}


bahwa nilai signifikeasi (sig.2-tailed) dengan uji-t adalab 0,00. Karena nilai signifikeasi lebih kecil dari 0,05 maka berdasarkan kriteria pengambilan keputusan, $H_{0}$ ditolak. Ini menunjukkan bahwa hasil belajar setelah menggunakan LKS ada perbedaan secara signifikan. Kemudian Uji-t Tes Akbir Soal Uraian Pretest dan Posttest terlihat bahwa nilai signifikasi (sig.2-tailed) dengan uji-t adalah 0,007. Karena nilai signifikasi lebih kecil dari 0,05 maka berdasarkan kriteria pengambilan keputusan, $H_{0}$ ditolak. Ini menunjukkan bahwa hasil belajar setelah menggunakan LKS ada perbedaan cukup signifikan. Dengan menggunakan analisis, hasil hipotesis menunjukkan bahwa penggunaan LKS dalam proses pembelajaran dapat meningkatkan prestasi hasil belajar siswa pada mata pelajaran Pendidikan Agama Islam di SMP Kota Bandung]

Kata Kunci: Pendidikan Agama Islam, Lembar Kerja Siswa, Prestasi

\section{INTRODUCTION}

In the course of a country's development, education plays an important role to ensure the survival of the state and nation, because education is a vehicle to improve and develop the quality of human resources. Today Indonesia face with a variety of problems posed by the development of a wide range of changes in the economic, social, political and cultural, as well as in the realm of education, all the hassles adorn almost every gap, therefore it changes into a demand and need. These nations are required to have high qualified human resources, competent and has a good performance that the audience not only has the dynamics of change and development in various sectors of life.

In education it is expected to build an independent human with critical thinking, creative, innovative, productive, responsible, social awareness, and noble personality. Basically education is an institution or government agency that seeks to teach and educate the nation's children to become adults who are intelligent and noble personality, as stated in the nation's ideals contained in paragraph four of the 1945 Constitution. With education, people will gain knowledge and experience that is expected to improve the welfare of the Indonesian people.

Education means the guidance given by a person to the development of others, in the direction of a particular ideals. As we all know, education is a process of formation of the whole man can be influenced by many factors supporting the creation of a perfect education. One is the existence of tools (media) education. Educational tool means an act or anything that can support the implementation of the educational process in order to achieve specific educational goals (Bahri \& Zain, 1997, p. 54)

Teaching and learning process is a process of educational interaction that takes learners on a new world that has never been experienced before. Educational interaction as social interaction generally involves all aspects of 
the overall communication, verbal and non-verbal communication to convey a message to others (Muhaimin, et. Al., 1996, p. 75)

Teachers are educational component that plays an important and role major, since the success of the learning process is determined by the teacher factor. The task of the teacher is delivering course material to students through communication interaction in the learning process is done. The success of teachers in presenting the material highly depend on the smooth interaction of communication between teachers and students. Disfluencies of communication shall due to the undelivered message brought by the teacher. In the interaction or communication, there are three elements, namely communicator (person delivering the message), the communicant (the person who receives the message) and the message itself. If one of the three elements is missing then the message delivery or interaction as the primary goal can not be achieved with either (Asnawir and Usman, 2002, p. 1)

Inside, there are several components of learning activities including: objectives, instructional materials, assessment, methods and tools. The four components is become the main component that must be met in teaching and learning. Components are not independent, but interrelated and mutually influence each other influence (interrelation).

In educational interaction, the message may include a description of certain topics. Teachers convey specific topic and ask to the same questions the students, as well as gives feedback and information about things necessary. Formal educational interaction is generally implemented in the classroom with limited automatic time and space intensive study. So the presence of these three elements is insufficient to achieve the educational interaction or learning the optimal. Therefore, it needs a media that can be used by teachers and students to facilitate learning material delivery to their students. So that students can be more easily understood the subject matter.

Teaching materials can be grouped into four, namely: (1) printed materials including handouts, books, modules, student worksheets, brochures, leaflets, wallchart, photos/images, models/mockups. (2) Instructional materials (audio), such as cassette, radio, phonograph records, compact discs and audio. (3) Instructional materials (audio visual) such as video compact discs, films. (4) interactive teaching materials such as an interactive compact disc (Majid, 2007, p. 174).

In addition, book support education learning. Even sometimes the book can be an indicator of students knowledge, the more books they read the more knowledge they have. In short, the book is a storehouse of knowledge, the most important tool and also one of the important means to improve the quality of education. The book contents are required to have a national standard of education. However, in reality the book that became the 
corner stone of education becomes difficult to reach from the price level. For the secondary school level, each child is required to purchase dozens of books with prices in the hundreds of thousands (http://bse.depdiknas.go.id/).

There are demands on the use of instructional media for a teacher to facilitate the delivery of learning to students. Instructional media, in addition to encourag effective teaching and learning process can also serve as a medium for the evaluation measure the achievement of learning outcomes. The extent to which a series lesson learning objectives can be achieved. Therefore, formal schools do not do a lot of breakthroughs in the study of media innovation, to strengthen student's memories.

In general, the basic functions of instructional media are; 1) saving teachers time in teaching. With the teaching materials a teacher can accelerate the learning process. If teacher takes a long time to take monotonous process, teaching and learning activities will be boring for students; 2) changing role of the teacher as facilitator. By becoming a facilitator, the learning process becomes more relaxed and participatory. Because not only teachers who have a lot to talk explains a lot. But students also play an active role to explain a thing or expressing opinions and his opinions; 3) enhancing the learning process to become more effective and interactive. Teaching and learning process with effective and interactive learning will lead to more optimal result. Targeted learning objectives can be achieved as planned well in advance (Bafadal, 2004, p. 4-5).

Characteristics of PAI in SMP is the effort of teachers or educators for to make their students believe, understand and practice the teachings of Islam through the activities of the guidance, teaching or training that had been planned to achieve intended purpose. In addition, the scope of PAI in SMP covers the basic elements of the Qur'an, Hadith, Aqidah Akbläq, Fiqh, Worship guidance and History (Tärikh) that more emphasis on the development of the religious teachings in science and culture.

Based on the background of the problems described above, the formulation of the problems that exist in this study are as follows: 1). Is there a difference between the students learning outcomes of subgroups of low and high subgroups with learning to use the media worksheets on Islamic Education subject? 2). What are the obstacles in the implementation of learning by using the worksheets on the subjects of Islamic Education?

This study is intended to use the quasi-experiment research of the difference learning outcomes of students using worksheets. Thus, in this study there was a treatment of one group. The design used in this study is a pre-test post-test one group. 
The variables of this study consists of two types of variables: independent variables and the dependent variable. Worksheets use in the learning process is independent variable, while the dependent variable is the student's learning outcomes. The instrument of this research involves a type of instrument is a written test. Instrument is in the form of a set of tests that test questions and multiple-choice test item description.

The written test was conducted prior in the beginning of the learning process and the time after the learning process that aims to identify improving student learning outcomes in writing about the implementation of the learning process using worksheets. The procedures in this study were: 1) conducting a preliminary study, 2) identifying and formulation of the problem, 3) defining research objectives, 4) the selection of research subjects, 5) establishing the control group and the experimental group, 6) performing pretest, 7) providing treatment in accordance with the design study, 8) doing the posttest, 9) analyzing of research data, and 10) inferencing the results of the study.

\section{FINDINGS AND ANALYSIS}

\section{Findings}

Pretest data are used to determine the ability of the students before the beginning of the use of worksheets. Pretest data was taken from scattered students. The score has a range of 0-100. From the results of the pretest data processing, a maximum value, minimum value, mean value and standard deviation are obtained as shown in the following:

Deviation

Table Maximum Value, Minimum Value, Mean and Standard Initial Test (Pre-test) Descriptive Statistics

\begin{tabular}{|c|c|c|c|c|c|}
\hline & $\mathrm{N}$ & Minimum & Maximum & Mean & $\begin{array}{c}\text { Std. } \\
\text { Deviation }\end{array}$ \\
\hline PRETEST & 30 & 21.74 & 86.96 & 57.2467 & 16.97776 \\
\hline POSTEST & 30 & 34.78 & 91.30 & 71.1603 & 13.86651 \\
\hline
\end{tabular}

The next step is to examine the data of multiple choice questions in order to know in advance whether the data came from a population that is normally distributed or not. Normality test used the Kolmogorov-Smirnova by using SPSS 18.0 for Windows with significance level of 0.05 . following:

After processing the data, the display output can be seen in the 
Table Distribution Normality Test Questions Multiple Choice

\begin{tabular}{|l|c|c|c|}
\hline \multirow{2}{*}{} & \multicolumn{3}{|c|}{ Kolmogorov-Smirnov $^{\mathrm{a}}$} \\
\cline { 2 - 4 } & Statistic & $\mathrm{df}$ & Sig. \\
\hline Pretest & .086 & 30 & $.200^{*}$ \\
\hline Posttest & .106 & 30 & $.200^{*}$ \\
\hline
\end{tabular}

Based on the results of the test output, the normality using the Kolmogorov-Smirnova significance of the data in the following table value is 0.200 for the pretest and posttest data for the significance value is 0.200. Both significance values are greater than 0.05 . Thus $\mathrm{H}_{0}$ is accepted. This means from the pretest and posttest samples come from populations that are normally distributed.

The normality of the data can also be viewed on the pretest normality Q-Q plot graphs the following:

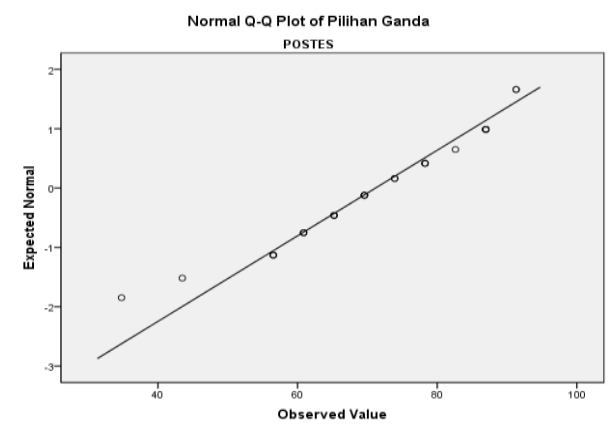

\section{Graph Distribution Normality Pretest Results}

Normality of the data can also be viewed on the posttest normality Q-Q plot graphs the following:

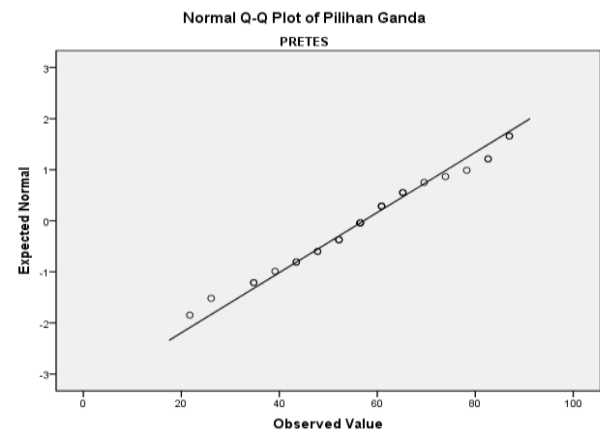

\section{Graph Distribution Normality Posttest Results}

After learning that the samples come from populations that are normally distributed, the next step is to test the homogeneity using Levene 
test statistics with SPSS 18.0 for Windows with significance level of 0.05 . This is done to see if the data comes from the same variance or not. following:

After processing the data, the display output can be seen in the

Table homogeneity of variance test and pretest Postest

\begin{tabular}{|c|c|c|c|}
\hline Levene Statistic & df1 & df2 & Sig. \\
\hline 2.493 & 7 & 19 & .054 \\
\hline
\end{tabular}

Based on the results of the test output homogeneity using Levene's test in the following table, the significance values are 0.54 . Since the significance value is greater than 0.05 then the decision criteria can be concluded that there is no difference between the posttest and pretest variance or in other words, the variance between the pretest and posttest are the same.

Based on the results of tests of normality and homogeneity tests that have been performed, the data obtained were normally distributed and homogeneous as to continue the average similarity test using the test two parties through SPSS 18.0 for Windows using paired T-test with a significance level of 0.05 .

After processing the data, t-test results are shown in the following:

T-Test Tables Multiple Choice Test Questions Posttest And Pretest

\begin{tabular}{|c|c|c|c|c|}
\hline \multicolumn{2}{|c|}{ Multiple Choice } & $\mathrm{t}$ & $\mathrm{df}$ & Sig. (2-tailed) \\
\hline Pair 1 & $\begin{array}{l}\text { Pretest - } \\
\text { Posttest }\end{array}$ & 4.537 & 29 & .000 \\
\hline
\end{tabular}

The following table shows that the values of significance (sig.2-tailed) with the T-test is 0.000 . Since the significance value less than 0.05 then the decision-making criteria, $\mathrm{H}_{0}$ is rejected. This suggests that the learning outcomes after taking treatment has no differences in Worksheets significantly.

Problem description test data were obtained from the pretest and posttest consisting of students. Scores were given to have the range of $0-100$. From the data processing for each class, it was obtained the maximum value, minimum value, mean value and standard deviation as contained in the following:

Table Maximum Value, Minimum Value, Mean, and Standard Deviation Data About Posttest Description and Pretest Descriptive Statistics

\begin{tabular}{|c|c|c|c|c|c|}
\hline $\begin{array}{c}\text { Value } \\
\text { Description }\end{array}$ & $\mathrm{N}$ & Minimum & Maximum & Mean & $\begin{array}{c}\text { Std. } \\
\text { Deviation }\end{array}$ \\
\hline
\end{tabular}




\begin{tabular}{|l|l|l|l|l|l|}
\hline Pretest & 30 & 20.83 & 91.67 & 63.4440 & 17.95302 \\
\hline Posttest & 30 & 45.83 & 95.83 & 74.2770 & 14.13038 \\
\hline
\end{tabular}

Normality of the two class test is done with the KolmogorovSmirnova using SPSS 18.0 for Windows with significance level of 0.05 . following:

After processing the data, the display output can be seen in the

Table Normality Distribution Problem Description Posttest and Pretest

\begin{tabular}{|l|r|r|r|}
\hline \multirow{2}{*}{ Problem Description } & \multicolumn{3}{|c|}{ Kolmogorov-Smirnov } \\
\cline { 2 - 4 } & Statistic & df & Sig. \\
\hline Pretest & .146 & 30 & .104 \\
\hline Posttest & .137 & 30 & .157 \\
\hline
\end{tabular}

Based on the results of the test, output normality using the Kolmogorov-Smirnova in the following table significant value in a column about the significance of the data description of the pretest scores were 0.104 and 0.157 on the posttest. Both the significance values are greater than 0.05 , and based on the decision-making criteria then $\mathrm{H}_{0}$ is accepted. This means a sample of normally distributed population.

Normality of the data from the pretest and posttest can also be seen in the chart of normality Q-Q plots following:

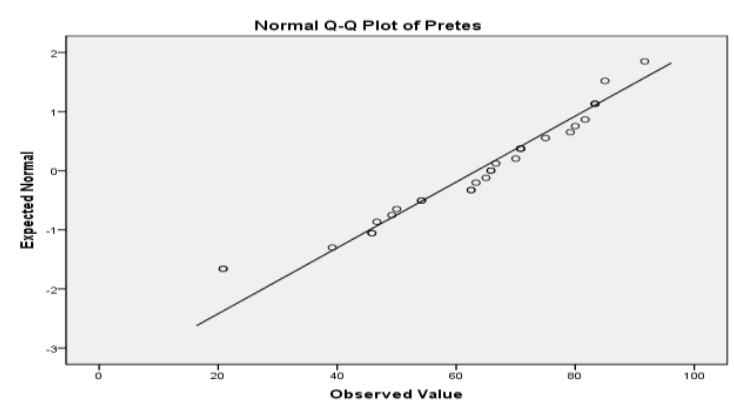

Normality Test Chart With Q-Q Plot Problem Description Pretest

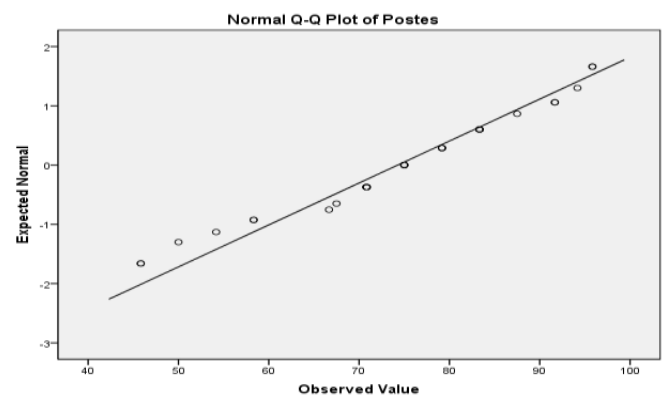


Normality Test Chart With Q-Q Plot Problem Description Posttest

Based on table, the graph looks a straight line from the lower left to the upper right. The point prevalence of a line indicates whether or not a normal data. If a normal distribution of data, then the data will be spread around/about the line. From the graph above shows that the data are scattered around a straight line. It can be concluded that the data about the test and pretest posttest description for normal distribution.

In a test of normality is known that the samples come from populations that are normally distributed, the next step is to test the statistical homogeneity using Levene test with SPSS 18.0 for Windows with significance level of 0.05 . This is done to see if the data comes from the same variance or not. following:

After processing the data, the display output can be seen in the Test of Homogeneity of Variances Problem Description

\begin{tabular}{|c|c|c|c|}
\hline $\begin{array}{l}\text { Levene } \\
\text { Statistic }\end{array}$ & df1 & df2 & Sig. \\
\hline 2.259 & 7 & 16 & .084 \\
\hline
\end{tabular}

Based on the results of the test output homogeneity of variance using Levene's test in the following table significance value is 0.084 . Since the significance value is greater than 0.05 and is based on the decision-making criteria then $\mathrm{H}_{0}$ is accepted. This means that there is no difference between the posttest and pretest variance or both have the same variance/Homogeneous.

Based on the results of tests of normality and homogeneity tests found that the data were normally distributed and homogeneous, so as to continue the average similarity test using the $t$ test of the party through SPSS 18.0 for Windows using paired T-test with a significance level of 0.05 . The hypothesis of mean equality test is as follows:

$\mathrm{H}_{0}$ : There was no significant difference between the learning outcomes of students who were using worksheets compare to the student learning outcomes using conventional learning.

$\mathrm{H}_{1}$ : There was a significant difference between the learning outcomes of students who were using worksheets compare to the student learning outcomes using conventional learning. 
Because the tests are carried out to test the one hand, the tests based on test criteria according Nurgana (Sutrisno, 2011, 59) that "accept $\mathrm{H}_{0}$ if $\mathrm{t}_{\text {bitun }} \leq \mathrm{t}_{1-a}$ and reject if $\mathrm{t}$ has other prices with significance level 0.05 ".

After processing the data, display the results of the final test $\mathrm{T}$-test (posttest) can be seen in the following table.

T-Test Table Test Final Problem Description Posttest and Pretest

\begin{tabular}{|c|l|c|c|c|}
\hline \multicolumn{2}{|c|}{ Problem Description } & $\mathrm{T}$ & $\mathrm{df}$ & Sig. (2-tailed) \\
\hline Pair 1 & $\begin{array}{l}\text { Pretest } \\
\text { Posttest }\end{array}$ & -2.898 & 29 & .007 \\
\hline
\end{tabular}

The table above shows that the significance value (sig.2-tailed) with the t-test is 0.007 . Since the significance value less than 0.05 then the decisionmaking criteria, $\mathrm{H}_{0}$ is rejected. This suggests that the learning outcomes after taking worksheets has difference significantly.

\section{Analysis}

In this study, the learning activities performed 4 to 6 times for meeting face-to-face in the classroom and 2 meetings for the pretest and posttest. Material presented in this research is based on the syllabus prescribed by the central curriculum consisting of 3 Standard of Competence, i.e.

1. Application of the Law Reading Qalqalah and $\mathrm{R} a$

The contents and scope of this material is that students are expected to read and analyze a variety of literature on reading law Qalqalah and $\mathrm{R} a$, so that may explain it well.

2. Increasing Faith To the Books of Allah

The contents and scope of this material are that students are expected to read and analyze a variety of literature and know the scriptures are there and can explain about faith in Allah books correctly.

3. Allowing To behave commendable

he contents and scope of this material is that students are expected to make observations about the behavior of people so that they can fully understand the concept of good behavior as zubud and tawakkal and have the ability to do so.

At the first meeting we was conducted a pretest and then analyzed. Pretest data were normally distributed and had homogeneous variance, and the mean similarity test and the $\mathrm{t}$ test showed that the students' prior knowledge on the pretest was the same.

After being given a different treatment, the researcher then held posttest at the end of learning. Posttest data analysis aims to determine how the effect of the use of worksheets on Islamic education student learning outcomes, whether it is better or vice versa. Once analyzed, the data were 
normally distributed and had posttest variances are homogeneous, then the mean similarity test and the $t$ test showed that student learning outcomes in subjects Islamic education after using worksheets turned out better than before that when students not using the worksheets.

The use of highly effective and efficient worksheets used in the learning process by open junior high school students when compared with other learning media such as textbooks/other literature books, this is because the worksheet has very distinctive characteristics in terms of its physical form, its content and in its use. According Lismawati (2010, p. 39), there are some characteristic of Worksheets them are as follows:

1. Worksheets only consist of a few pages, it was not until a hundred pages.

2. Worksheets are printed as specific teaching materials to be used by a certain educational level unit.

3. It comprises a brief description of the subject in general, a summary of the subject, dozens of multiple-choice questions and problems stuffing.

In general, the learning has been done goes well, so that the results of the analysis carried out in accordance to the hypothesis that has been expressed previously. Nonetheless, there are several obstacles when this research was conducted, among others, students did not accustomed to use worksheets, when students learn in a group there are some students who chatting so that time can not be effected and workmanship existing unfinished worksheets. When doing a presentation, students still looked nervous.

Although the learning process is expected to run independently by students of Open Junior High School, but still preferred the supervision of the teacher. Because we already understand the characteristics of the students when the learning process, there are times when they feel lazy and less excitable especially on Subjects they consider difficult or less to their liking in particular for this PAI.

The constraints faced by the researcher during the research process if associated with Lismawati opinion (2010, p. 40) is about pembelajaran media learning definitely has advantages and disadvantages, it is to the advantage and disadvantages of instructional media Student Worksheet is described by Lismawati (2010, p. 40) as follows:

1. The advantages of Student Worksheet media are:

a. From the aspect of usage: media is the most straightforward. It can be learned anywhere and anytime without having to use special tools.

b. From the aspect of teaching: learning than other types of media can be said to be superior. Because it is a sophisticated media in developing students' ability to learn about the facts and be able to explore the general principles and abstract using realistic argument. 
c. From the aspect of the quality of learning, it is capable of delivering a message describing words, numbers, music notation, twodimensional drawings, and diagrams with a very fast process.

d. From the economic aspect: It is economically less expensive compared to other learning media.

2. The disadvantages are:

a. Not being able to present the movement, exposure of the material is linear, not able to present the events in a sequence.

b. It is difficult to provide guidance to readers who have difficulty understanding certain parts.

c. It is difficult to give feedback to questions that have many possible answers or questions that need answers are complex and deep.

d. Not accommodate students with limited reading ability because the media was written at a particular reading level.

Based on the above opinion and research, the results can be drawn in the form of an implications of the advantages and disadvantages of the use of Student Worksheet On The Subject Of Islamic Education, among of any:

1. Student Worksheet media is the most practical for students, especially for students of Open Junior High School which is the object of this research.

2. Since the object of this research is the students of Open Junior High School that in fact they are children from poor families, the Student Worksheet is economically cheaper than other learning media.

3. Because the open nature of the SMP emphasizes learning independently, then the Student Worksheet is a suitable material for them as assistant in the learning process.

4. Because of the nature of the Student Worksheet that number has few of pages, so the students do not have the material enrichment of the existing discussion. This be cores out of disadvantages of this student worksheet.

\section{CONCLUSION}

Based on the research results, it was obtained some conclusions as follows; 1) The results of the analysis that the T-Test of the Test Questions Multiple Choice Pretest and Posttest seen that the value of significance (sig.2tailed) with the t-test is 0.00 . Since the significance value is less than 0.05 then the decision-making criteria, $\mathrm{H}_{0}$ is rejected. This shows that learning outcomes after the use of worksheets is no significant difference; 2) The results of the analysis that the T-Test of the Test Problem Description Pretest and Posttest is seen that the value of significance (sig.2-tailed) with the t-test is 0.007 . Since the significance value is less than 0.05 then the decision-making criteria, $\mathrm{H}_{0}$ is rejected. This shows that learning outcomes 
after the use of worksheets has significant difference; 3) The results showed that the use of worksheets hypothesis in the learning process can improve the achievement of student learning outcomes in subjects of Islamic teaching in junior high school at Bandung-Indonesia; 4) In addition to facilitate teachers in delivering learning materials, Worksheets is expected to be a medium or practical instructional materials for also being not only helping to understand and facilitate student learning, but it became media that can improve student achievement.

\section{BIBLIOGRAPHY}

Asnawir \& Usman, Basyiruddin. (2002). Media Pembelajaran. Jakarta: Ciputat Pers.

Bafadal, Ibrahim. (2004). Manajemen Perlengkapan Sekolah: Teori dan Aplikasinya. Jakarta: Bumi Aksara.

Bahri, Syaiful and Zain, Azwan. (1997). Strategi Belajar Mengajar. Jakarta: Rineka Cipta.

http://bse.depdiknas.go.id

Majid, Abdul. (2007). Perencanaan pembelajaran mengembangkan standar kompetensi guru. Bandung: PT Remaja Rosdakarya.

Muhaimin. et al. (1996). Strategi Belajar Mengajar: Penerapan dalam Pembelajaran Pendidikan Agama. Surabaya: Karya Anak Bangsa. 